from Michigan Business Review • July 1970

\title{
Putting a Dollar Value on Human Assets
}

\author{
WILLIAM C. PYLE \\ Director of Human Resource Accounting Research \\ University of Michizan
}

EVERY YEAR industry spends billions of dollars acquiring and developing longterm human capabilities. However, accountants treat all such outlays as operating expenses that assume their benefits are confined to the short term. Because of this practice, the management of human resources is impeded in the following ways:

- Humar resources are not reflected in the firm's capital budget. In contrast to physical plant and equipment, it is therefore more difficult for the manager to justify funds for building human assets since these expenditures are currently charged against revenue in one year. When an organization is, in effect, investing more heavily in creating new human capabilities than they are being consumed, conventional accounting practice actually overstates operating expenses and understates profitability.

- Conversely, improper maintenance of human capabilities before the projected replacement date may not be detected. If unmeasured human assets expire prematurely, write-offs are not recorded; when human capabilities are being liquidated more rapidly than they are being created, conventional accounting practice understates operating expenses and overstates net income.

- It is also difficult to determine how well humar assets are being utilized in various projects. One of the most commoniy employed measures of overall efficiency is the return generated on invested capital (ROI). However, investments in human resources are not included in ROI calculations for evaluating current or future projects.

The objective of human resource accounting is to remedy these informational deficiencies by developing and integrating financially oriented measurement techniques to facilitate the management of an organization's people resources. Are sufficient human capabilities being ac-

Michigan Business Review (July 1970), (C) 1970 by The Unidersity of Michigan 
quired to achieve the objectives of the enterprise? Are they being developed adequately? To what degree are they being maintained? Are these assets being properly utilized by the organization?

\section{Managing Human Resources}

How should the development of human resource accounting proceed? First, the subject of managing human resources cannot be separated from management in general. Human capabilities are a resource to be managed in their own right; however, they also control or at least influence the other factors of production. Thus, the success an executive enjoys in the management of human capabilities may be expected to have a multiplicative impact on the overall effectiveness of the enterprise.

Second, it should be emphasized that managerial and informational systems are highly interrelated. An otherwise effective managerial system is not likely to succeed unless it is supported by an adequate informational system. Similarly, an otherwise useful informational system will be of little use if it is linked to a basically unsound managerial system. However, if one system should take precedence over the other, it seems reasonable to suggest that the informational system should be specifically tailored to support the managerial system. If executives are to employ accounting data usefully, they must be able to relate them to their own informational needs, which, in turn, are rooted in the managerial system that assigns particular roles and responsibilities to them. For this reason, the development of human resource accounting should be based upon a consideration of the general subject of management.
All managers are responsible for guiding business operations. For example, production managers requisition various materials and labor resources that become a part of or are directly consumed in the process of producing a product. Similarly, the personnel executive is also a manager of a business operation. For instance, he receives requisitions that initiate the process of acquiring new employees for the operating departments. Tasks such as these are usually performed over relatively short time cycles, say, less than one year.

In addition to business operations, all executives have responsibilities for managing the long-term productive capabilities that sustain these operations. Financial capabilities include, for example, liquidity and solvency. Physical capabilities exist in the form of the productive capacity and expansion potential of plant and equipment. Human capabilities are present in both the aptitudes, skills, and experience of individual employees and the leadership skills, team skills, and cooperativeness found in the organization. Informational capabilities include the accounting, financial, and systems capabilities that managers rely upon to guide their work. Executives also have varying degrees of responsibility for the external capabilities, of course.

Business capabilities do not become a part of the firm's final product nor should they be unduly consumed in its production. For this reason, the management of these capabilities normally takes a much longer time perspective than the management of current operations.

In managing operations and capabilities, executives employ both resources and processes. The resources may be financial, 
physical, human, and informational. Some of these inpurs are consumed in the course of operations, while others are employed to create long-term capabilities. Managerial processes such as planning, taking action, and controlling are also common to managing both operations and capabilities. The integrated performance of these two basic tasks leads to organizational results that are assessed against established objectives. The degree to which the desired results are achieved provides feedback that leads to modification of objectives and the various managerial activities.

\section{Current Information}

What financial information does the manager receive to assess the effectiveness of business operations? The most widely used measure of overall organizational efficiency matches revenue from the sale of the firm's product or service with the costs incurred to produce that revenue. In oversimplified terms, the difference between revenue and expenses is the profit or loss associated with a particular business operation.

Accountants exercise particular care to ensure that revenue is properly matched with associated expenses to determine net income. Otherwise, distortions in profit measurements will result. For example, capital expenditures for plant and equipment items are not charged off against revenue in one year. Rather, these costs are matched against revenue generated over the expected lives of the assets. However, costs incurred for building long-term human capabilities are all treated as expenses that understate revenue in the short term. Accordingly, measures of the efficiency of business operations are distorted.
Corresponding informational deficiencies are also present in financial data used to evaluate the management of certain longterm business capabilities.

Short-term measures of operational efficiency do not ensure that long-term business capabilities are properly managed. For example, it is well known that indicators of profitability may be improved if physical resources such as plant and equipment are improperly maintained or are used too intensively. For this reason, managerial and informational systems should be designed to give specialized attention to both business operations and capabilities.

The accounting profession has not been unmindful of the fact that measures of the efficiency of operations are inadequate to the task of insuring that productive capabilities are properly managed. For certain capabilities at least, accountants currently provide the manager with additional information indicating how well they are being acquired, developed, maintained, and utilized. For physical resources, accountants recognize costs incurred in acquiring plant and equipment as long-term invesments, which appear on the firm's balance sheet as assets. These expenditures, unlike expenses, are not matched against short-term revenue in measuring profitability. These investments are written down or amortized over the period of expected benefit. However, if such capabilities expire prematurely because of improper management or for other reasons, the investment is written down more rapidly than planned under the original amortization schedule. Such a premature write-off or loss becomes an expense item which is then matched against revenue during the current year. 
Accordingly, reported profitability is reduced and the responsible manager is held to account.

Unfortunately, the protection given to physical assets has not been extended to their human counterparts. One major objective of human resource accounting is to remedy this informational deficiency.

\section{Two Approaches}

Two interrelated approaches to human resource accounting are being pursued in a University of Michigan project sponsored jointly by the Institute for Social Research's Center for Research on Utilization of Scientific Krowledge and the Graduate School of Business Administration. The first approach relies upon extending to human resource accounting concepts and procedures that are currently employed in the management of physical and financial resources. Dollar investments in human capabilities are now being recognized. Once incurred, such investments are amortized over their expected useful lives. If they expire prematurely due to early employee separations or skill obsolescence, losses or write-offs are reported to management.

Monitoring human resource costs is only a partial answer to the informational needs of the manager. In themselves, these data do not adequately reflect the value of human resources. How can return on invesments in human resources be determined? How can the worth of different leadership styles, team skills, and cooperativeness be measured?

The second approach to human resource accounting focuses on the development of alternative means for assessing the productive capability of human resources and how this may be changing through time.
Although some insight into this question may be gained through extension of conventional financial analyses to human resources, much greater reliance is being placed upon the use of social psychological measurement techniques such as those developed by Rensis Likert and his colleagues at the Institute for Social Research. This approach to human resource accounting will be discussed after the investment measurement approach is examined.

\section{- Investment Measurement}

The "cost approach" to human resource accounting has been developed in collaboration with the management of the $R$. G. Barry Corporation, of Columbus, Ohio. The firm's 1,700 employees are engaged in the manufacture of a wide variery of personal comfort items, including foamcushioned slippers, sandals, robes, pillows, and other leisure goods marketed nationally in leading deparment stores and other outlets. The corporate headquarters and four production facilities are in Columbus, but several other plants, warehouses, and sales offices are located across the country. The firm has expanded from a sales volume of about $\$ 5^{1 / 2}$ million in 1962 to over $\$ 25$ million in 1969 .

It had become increasingly apparent to the firm's president, Gordon Zacks, and personnel vice-president Robert L. Woodruff, Jr. that success in the business was crucially linked to the firm's human resources. Physical capital requirements were relatively low and entry into the industry was not seriously impeded on that count. Rather, success was more closely related to excellence achieved in acquiring, developing, maintaining, and utilizing human and customer-loyalty assets. The cor- 
poration faced the problem that its conventional accounting system maintained detailed surveillance over the relatively less important physical assets, but failed to recognize the more important human and customer-loyaity assets. This situation led Mr. Zacks and Mr. Woodruff to discuss the problem with the University of Michigan's Institute for Social Research.

When the research effort began, the writer had proposed only rather general concepts for measuring dollar investments in human resources. In late 1966 , a joint university-industry team was formed to consider the problem in more detail. This continuing group is composed of the author and a team of R. G. Barry managers, which, in addition to the president and personnel vice-president, includes the treasurer and controller. During the first half of 1967 , the team members met regularly to develop a set of theoretical constructs for categorizing and measuring the ways in which a firm invests in its human organization. The rest of the year was devoted to translating these concepts into detailed procedures for recognizing investments in human resources as well as expirations which might occur in these assets.

In January 1968 an investment accounting system was established for the firm's managers and in June 1969 this system was extended to cover factory and clerical employees in two plants. Last July, two additional plants were included in the system. At the end of the first quarter of 1970, the R. G. Barry Corporation reported a "book value" figure of $\$ 1,765,100$ based upon 147 managers and 425 factory and clerical personnel. On an individual basis the firm invests approxi- mately $\$ 3,000$ in a first-line supervisor, $\$ 15,000$ in a middle manager, and upwards of $\$ 30,000$ in hiring, orienting, and developing a top-level executive.

For internal management purposes, the Barry Corporation in the latter part of 1969 prepared what is believed to be industry's first capital budget for human resources. Expenditures undertaken with the objective of building long-term capabilities are charged against revenue over the period of expected benefit. Managers receive quarterly human resource reports based upon the plans they have submitted and indicating the "book value" of investments in their subordinates at the beginning and end of the quarter. Increases and decreases occurring during the period are also highlighted.

Human resource accounting techniques are not only employed to evaluate the performance of current operations, but are also used in analysis and selection of new business opportunities. President Zacks describes this application:

We use human resource accounting information in strategic decision making. The information is employed in evaluating altemative investment opportunities. We have rejected the conventional retum-on-assets approach because it does not recognize human investments. In evaluating a project, we take the physical assets into account as everyone eise does, but we also add to that investment to be made in the human resources required to support the opportunity. And when we develop relationships to profit, it is the relationship of all of these resources, tangible and human, to a particular profit opportunity.

The report format may also be used as a device to evaluate new business opportunities. The required capital expendirures for human resources (and write-offs of 
prior investments) may be projected and included along with similar information for the physical resources associated with each option under consideration. When a particular opportunity is selected, these data then serve as the plan against which actual experience is reported. In addition to special-purpose analyses such as these, human resource data are also being integrated with the firm's conventional financial statements for internal management purposes.

\section{Financial Statements}

The Barry Corporation's 1969 annual report contained industry's first published financial statements to include human resource data. This information was contrasted with the conventional financial statements in a special section of the report dealing with human resources. Net investments in managerial personnel of approximately a million dollars were recognized. The liabilities and stockholders' equity side of the balance sheet indicated approximately $\$ 5,000,000$ for "Deferred Federal Income Taxes as a Result of Appropriation for Human Resources" and an equal amount for an "Appropriation for Human Resources" under retained earnings.

In the income statement, a net change of $\$ 173,569$ in human resource investments during 1969 was applied as a positive adjustment to income before taxes. After taxes, this change resulted in an upward adjustment of about $\$ 87,000$ to conventionally determined ret income of about $\$ 700,000$, reflecting the fact that during 1969 new investments in human resources were undertaken more rapidly than they were written down.

The primary purpose for developing hu- man resource accounting at the $R$. G. Barry Corporation is to improve internal management. However, treasurer Edward Stan aiso believes such data will eventually be employed by parties outside the business:

Although a milestone has been reached by incorporating human resource accounting data into a published balance sheet and profit-and-loss statement, the true significance will not be apparent until comparative years are available. In order for these data to become useful for outside financial analysts, a credibility must be established and an activity-results pattern set up. Once this has been accomplished, the analyst, whether he is investor or lender, will have an important additional tool for his decision making.

Evidence suggests that influential segments of the accounting fraternity would also welcome such a development. For example, a committee of the American Accounting Association has proposed that procedures be developed for allocating expenditures for personnel recruitment and training to asset and expense categories. Sidney Davidson, of the Accounting Principies Board of the American Institute of Certified Public Accountants, also advises that costs incurred for such purposes be carried as assets and amortized against future earnings.

Human resource accounting may help the manager gain insight into the value of human assets in several ways.

- Measuring retum on assets employed. As noted earlier, one of the most commonly used measures of value is the return generated on assets employed in a business undertaking. However, capital outlays for human resources are not included in ROI calculations used to evaluate current or future projects. The addition of human resource data will im- 
prove these measures, especially where the ratios of human to other assets vary significantly across profit centers or projects being compared. Thus, conventional measures of value may be made more reflective of the human contribution. However, these calculations do not usually identify that portion of the return associated with the human component alone.

- Measuring return on investments in human resources. If a profit center is highly human-resource intensive, an ROI measure will indicate what is essentially a return on human capital. In most instances, ROI calculations reflect the product of a "resource mix"; in such cases it is difficult, if not impossible, to link a certain portion of the return to human resources. However, where adequate performance criteria and relatively stable environmental conditions exist, insight into this question may be gained through controlled experiments. Human resource investments may be varied while other factors are held constant to the degree possible. For example, one type of recruiting practice may be followed for experimental groups while another may be pursued for control groups.

In the absence of reliable performance eriteria or where dynamic environmental factors preciude controlled experiments, ROI trends may be estimated through indices based upon social-psychological measurement techniques. For example, members of work groups can be asked the degree to which they believe prior investment in recruiting or development have been effective. If such data show that employees perceive a lowering in the quality of new hires, this information will at least alert the manager to the fact that retum on investments in recruiting may be fall- ing off, even if it cannot be quantified in monetary terms. Data such as these are being collected annually at the $R$. G. Barry Corporation.

- Adjusted costs. Conventional asset valuations are based upon historical costs less depreciation. A similar treatment has now been extended to human resources. When an organization invests in a new employee, it does so with the obvious expectation that returns will exceed the costs involved, even though this value cannot usually be quantified. Thus, it is reasonable to suggest that historical costs at least represent a minimum statement of the average position holder's value. Despite the inherent limitations of cost information alone, it is possible to make these data more reflective of the value of human resources. For example, historical costs may be adjusted upward or downward according to changes in the replacement cost of personnel, the expected tenure of employees, and the performance and/or potential of personnel.

Like their physical resource counterparts, historical investments in human resources are "sunk costs." Although these data may be usefully employed as a basis for evaluating prior invesments, the cost of replacing human capabilities provides the manager with a closer approximation of an individual's value to the organization. If a particular position should become vacant, it would not be rational to hire a new employee unless it was expected that he will contribute something in excess of the replacement costs involved. This kind of information is especially useful in long-range manpower planning. Cost standards developed at the $R$. G. Barry Corporation are periodically updated for such purposes. 
Although replacement-cost data are a closer approximation of value than historical costs, they do not necessarily reflect a particular individual's value to the organization. The worth of an employee is a function of two interrelated variables, his expected tenure and the quality of his contributions over that period of time.

For amortizing investments in human resources, cost-less-depreciation information (or "book value") indicates thatother things being equal-the employee with more expected tenure is of greater value to the organization than the one with a lesser amount of remaining service. This kind of information for human resources might appear to be no more reflective of value than similar information currently reported for plant and equipment items, but different procedures have been adopred for human resources because of the fact that employees, unlike capital equipment, can, in large measure, vary their own length of service. For this reason, the expected tenure of personnel is periodically reassessed in the light of changes in factors that influence length of service. For example, the book value of an employee may actually be greater after he has spent one year on the job because the probability of his staying longer with the organization is greater at that time. Some of the other major variables that affect tenure include a person's age, organizational level, and degree of job satisfaction. A crucial component of human resource accounting research focuses upon identification of relationships between changes in such factors and variations in expected working life.

Human resource book values are revised periodically with the following formula:

\author{
Expected remaining tenure $=$ \\ Present tenure + \\ Expected remaining tenure \\ $\times$ Current replacement cost
}

It should be emphasized that changes in book value are more important than the absolute figures. The directions of trends in such data are accurate indicators of changes in the value of employees whose performance remains relatively constant. This condition tends to prevail in many operative jobs where performance is determined largely by physical technology or in more highly skilled positions if performance is uniformly high. However, such uniformity frequently does not prevail and further adjustments may be required to make human resource cost data more reflective of changes in value.

Human resource costs may be adjusted still further to reflect changes in an individual's performance and/or potential. For example, book values can be adjusted positively or negatively in relation to changes in various employee ratings. In such cases, valuations may well exceed current replacement costs. The range of these adjustments can be based upon dollar estimates of the degree to which an individual may benefit (or harm) the organization. Very little research has been conducted in this area, and judgments as to the potential usefulness of such information must be deferred at this point.

\section{Assessing Groups}

Most of the research undertaken in human resource accounting has dealt with measurement of investments in individual employees. However, it is well known that human resource value not only exists in capabilities of individuals, but is also de- 
pendent upon the effective interaction of employees. To be complete, human resource accounting must also assess the productive capability of various organizational groupings and how this may be changing through time.

For over two decades, the Institute for Social Research, under the leadership of Rensis Likert, has been developing concepts and techniques for measuring the 50cial-psychological properties of organizations and how they change through time. "Causal variables," such as organizational structure and patterns of management behavior, have been shown to affect "intervening variables" such as employee loyalties, attitudes, perceptions, and motivations, which in turn have been linked to changes in conventionally measured "end-result variables," such as productivity and earnings. These measures reflect changes in the productive capabilities or value of an organization's human resources that cannot be adequately mea- sured through costs alone. However, both measurement concepts need to be considered, as it is through variation of costs that managers exert a major influence on the value or future productive capabilities of both the human and physical resources of the business.

What is the outlook for development of human resource accounting in industry? The measurement of investments in human resources employs concepts and procedures that are generally familiar to financial analysts. Many measurement problems remain here, but these are no more troublesome than those typically encountered in accounting for physical assets. However, the measurement tools of the social scientist do not have their counterparts in accounting for physical resources. This at once presents a new measurement opportunity, but it also poses the problem of acclimating financial people to basically new measurement techniques unique to human resources. 